\title{
Impact of Teacher-Gender on Primary Students' Achievement: A Study at Malaysian Standpoint
}

\author{
Kazi Enamul Hoque \\ Faculty of Education, University of Malaya, Kuala Lumpur, Malaysia \\ Email-keh2009@um.edu.my \\ Ahmad Zabidi Abdul Razak \\ Faculty of Education, University of Malaya, Kuala Lumpur, Malaysia \\ Mosa. Fatema Zohora \\ Faculty of Education, University of Malaya, Kuala Lumpur, Malaysia \\ Reazul Islam \\ Asia-Europe Institute, University of Malaya, Kuala Lumpur, Malaysia
}

Accepted: Jan 17, 2013 Published: Feb 23, 2013

Doi:10.5296/jsr.v4i1.3295 URL: http://dx.doi.org/10.5296/jsr.v4i1.3295

\begin{abstract}
This study attempts to find the impact of teacher-gender on primary student achievement. The quantitative method of research was used for this study. This study, first in its nature in Malaysia, uses test scores of primary grades for five consecutive years which is obtained from a school in Kuala Lumpur. This study engages a total of 1 school, 20 classes, 30 teachers and 604 students. The overall finding in this study is that women are slightly better to teach in primary when the test scores are analyzed. Although there are some differences in the breakdown analysis, the combined result analysis do not find strong evidence to claim whether students have to be taught by teachers of same or alternative gender. The findings of this study provide important information for the policy makers and especially for the primary teachers' recruiters in primary schools of Malaysia.
\end{abstract}

Keywords: Teacher-gender; primary school; student achievement

\subsection{Background of the study}

The bulk of statistics around the world consistently confirms that teaching profession is predominantly held by the feminine gender. Congruently, growing concerns assert that boys have been continuously under performing in schools as compared to girls. This pattern of results led to the assumption that boys' underperformance is due to the underrepresentation of 
men in the teaching profession. As such, policies have being recommended to increase recruitment of male teachers in countries like UK, Australia, USA, Finland and New Zealand (Carrington, Francis, Hutchings, Skelton, Read, \& Hall, 2007). As a result, research in education and gender which were previously much focused on gender differences in student achievement, has been diverted to the effect of teacher gender on student achievement. The present study is a contribution to the existing researches on the impact of teacher gender on student achievement examining the fundamental question of whether men or women are more suitable to teach in primary grades.

Despite many challenges most importantly ethnic and religious diversity, Malaysia has made remarkable achievements in meeting local and international standards in terms of education. Early childhood care and education has been expanded, primary education has been universalized, secondary education has seen marked growth, illiteracy has been nearly eliminated, and higher education opportunities have been expanded by establishing many public and private universities since 1990. Moreover, Malaysia has been successful in achieving the Millennium Development Goals far ahead of the target year (Planning Commission, 2009).

Like most of the developed countries, statistics for Malaysia show that the number of females in the teaching profession far outweighs the number of males. Based on statistics available (Malaysia, 2010), there are a total of 229,921 primary teachers in the country out of which 159,276 are females. This represents $69.3 \%$ of the total teachers. Looking into the share of teacher gender in primary schools, it is found that $30.7 \%$ of primary teachers are males. Although not much severe, the gender gap in student achievement also depicts similar results in Malaysia. The findings of Majzub and Rais (2010) indicated mixed results on teacher preference and effectiveness agreement towards increasing male teachers, support for a co-education system, and the need for developing teacher professional development program.

Recently, there have been several arguments that boys' under achievement in education is due to female dominance in the teaching profession (Driessen, 2007; Carrington \& McPhee, 2008; Skelton, 2002). The underlining argument for this is that lack of male role models could have negative consequences for the achievement and behaviour of boys (Driessen, 2007). If the argument is true, it indicates that immediate steps are necessary in order to ensure gender equity in education. As the statistics for gender representation in teaching profession and also the gender gap in student achievement in Malaysia is consistent with the rest of the world, it became necessary that such a study be conducted in the context of Malaysia. Owing to what has been explained in the preceding discussion, it is logical to appeal for policy recommendations that were put forward in the western countries. As such, a gender related study is significantly important before implementing such policies. Hence, the purpose of this study is to examine if the gender of the teacher has any impact on student performance in the primary school. 


\subsection{Research Questions}

In order to achieve the objectives of the research two fundamental research questions (RQs) have been deployed. The first research question compares the average marks of the classes against teachers' gender. The second research question compares the average of each group of students (i.e., boys and girls separate) against teachers' gender.

1. Is there any difference between male and female teachers based on students' test results?

2. Is there any difference between male and female teachers based on students' test as compared to their gender?

\subsection{LITERATURE REVIEW}

Since mid 1990s the studies were found to be increasing focused on the concerns of feminizing the education especially in the primary which led to such arguments as under representation of male teachers lead to lack of male role models in education and hence lower boys' performance (Driessen, 2007). In this section, the findings of these studies are presented under three subheadings- (1) those studies which focused on finding the effect of matching teacher and student gender, (2) those which focused on teachers' gender and its impact on student achievement, and (3) those which focused on gender differences in the types of relationships between teachers and students.

\subsection{The gender match}

The vast majority of studies in this line of research are concentrated in Britain due to the recommendation of the policy makers to increase recruitment of male teachers owing to the assumption that boys' under achievement in education is caused by underrepresentation of men in teaching. Almost all studies, however, find contrary evidence to the policy recommendation that matching students with the gender of the teachers does not necessarily bring in any positive outcomes in student performance.

The study by Carrington et al., (2007) reported results which are contrary to the famous policy recommendation. In this qualitative study, the researchers interviewed 300 elementary school students in England in order to understand their perception of better teachers whether males or females. The study revealed that the gender of teachers had little apparent effect on the academic motivation and engagement of either boys or girls. Instead, students value teachers who were consistent and supportive regardless of their gender. Research with similar types of designs in Holland confirmed that teacher sex has no affect whatsoever on the achievement, attitudes or behaviour of pupils (Driessen, 2007). The policy of recruiting 
more men into primary education to ensure demonstration of male role models has also been criticized by Jones (2003). By exploring the views of female teachers in the primary, the study concluded that recruiting more males should not necessarily improve boys' performance. The researchers postulated that the recruitment process should rather be focused on selecting the "right kind of men". Similarly, the study by Skelton, (2002) also reported that both students and teachers reject the notion that students perform better when matched by the teacher"s gender. Moreover, it was reported that the abilities of the individual teacher is more important than gender and sort of student teacher relationships (Francis, Skelton, Carrington, Hutchings, Read, \& Hall, 2008). Although the majority of the researches report that gender matching does not necessary improve student performance, there are yet some studies which indicate positive impacts of gender matching. The study by Carrington \& McPhee (2008) examined the commonly held belief that the gender gap in achievement stems from the shortage of male role models in teaching, especially at primary level. The researchers were much attracted by the existing literature on the influence of teacher gender on classroom interaction and educational outcomes which argue that students perform better when taught by teachers of the same gender. The(Carrington \& McPhee, 2008) study found that the majority of those interviewed believe that increasing the number of male teachers would ultimately serve to reduce the gender gap in achievement by increasing boys ${ }^{\text {ee }}$ academic engagement.

Other studies also found results supporting positive effects of gender matching. It has been reported that assignments of a same gender teacher significantly improves the performance of both boys and girls (Lam et al., 2010). The study by Dee (2007) investigated the prevailing beliefs that gender gap in student outcomes is a result of interactions between teachers and students. The study reported that matching gender of the teacher with that of the students is associated with better student performance.

\subsection{Teacher gender and student achievement}

Quite a number of studies have been conducted in this line of research. In this regard, after a collaborative study of 180 struggling boy readers in Grades 3 and 4 over a 10-week period, four professors from the University of Alberta and the University of Winnipeg (Canada) concluded that these students performed better when taught by a female teacher (ORegan, 2007). Although it is concluded as such the authors also highlighted some of the other factors such as the teaching materials used, the interest level of the students towards the subject, the family background and socio-economic status of the students and so on which could have some impact on student performance. Interestingly, all the 180 students who were chosen to participate in this programme were from low socio-economic status backgrounds, improved their performance regardless of teachers' gender although students from the female teachers were found to be more confident in reading. Karieg (2005) explored the impact of student and teacher gender differences on standardized tests using a large set of data on a longitudinal basis. This study reported three interesting findings: (1) boys perform worse and obtained less scores on mathematics, reading and writing as they move from third grade to fourth grade, (2) 
students of male teachers perform worse as compared to those of female teachers regardless of students' gender, (3) there is no significant difference between the performance of boys and girls of male teachers. Out of these findings, the final one is in strong support of what has been largely found by the researches on the impact of gender matching.

After interviewing with a number of students (Myhill \& Jones, 2006) found out that on one hand teachers of either gender tend to treat boys negatively as compared to girls while one the other and they also expect girls to perform better both in terms behaviour as well as academics. Based on this, it is more logical to appeal that boys' underperformance is due to differential treatments between boys and girls rather than being taught by a female teacher. The study also found out that male teachers tend to be biased by gender whereas female teachers are perceived to be less influenced by gender expectations. A large scale study done in Hong Kong with 148 primary teachers and 4867 grade 4 pupils found that students of both gender perform better when taught by woman (Lamet al, 2010). This study found contrary evidence to those studies which report that boys perform better when taught by men. The findings of a longitudinal study in Mexico showed results consistent with many other researches that there is evidence that students of female teachers perform comparatively better than those of males (Luschei, 2011). The researcher, however, argue that this does imply that male teachers are less effective - rather it could be due to some other related factors.

After examining data from longitudinal studies (Ehrenberg, Goldhaber, \& Brewer, 1995) reported that test scores of white female students in mathematics and science did not increase more rapidly when the teacher was a white woman than when the teacher was a white man. The study, however acknowledged that white female teachers evaluated their female students more highly than did male teachers.

The studies reviewed so far depict that females are somewhat better than males in teaching to primary students. Nevertheless, a fair number of studies have in fact found contrary evidence to this. A study conducted for year 3 elementary school pupils and their teachers revealed that both students and teachers perceive that the gender of the teachers does not matter as such with regard to student motivation and interactions, and consequently the performance of the students as well (Skelton, Carrington, Francis, Hutchings, Read, \& Hall, 2009). The majority of the respondents believe that it is the traits and qualities of the teacher that play a more significant role than gender stereo-types.

\subsection{Teacher gender and student-teacher interactions}

The gender differences in the interactions between students and teachers have been an interesting line of research on the topic. The vast majority of existing literature suggests that male and female teachers demonstrate different behaviour in their classroom interactions with the students. In this regard, females are found to be more approachable, easy to communicate and supportive whereas male teachers are found to be more strict and authoritative (Meece, 
1987). A study by (Rodriguez, 2002) which involved a survey of teachers indicates that male teachers are likely to select a more aggressive disciplinary approach toward boys. The study also reported that teachers of both gender tend to consider minor disruptive behaviour of girls than that of boys. Hopf \& Hatzichristou (1999) conducted a study to examine gender-related differences in student-teacher interactions in Greek classrooms focusing on teacher gender. Although the study was not an attempt to compare student results, it was found that teacher gender stereotyping has a greater impact on several factors such as perceptions, interactions, and expectations, as well as children's functioning and development. Carrington, Tymms, \& Merrell (2008) studied empirical data from British primary education to test the hypothesis that male teachers produce more positive attitudes amongst boys and female teachers amongst girls. The results gave little support for those who advocate boys perform better when taught by male teachers and girls performs better when taught by female teachers.

An experimentally designed study of a group of boys and girls revealed that female teachers tend to give most of their sex-role connected rewards for feminine behaviour to both boys and girls while on the other hand male teachers rewarded more equably, masculine behaviours for boys, feminine behaviours for girls (McCandless, Bush, \& Carden, 1976). On the other hand, after observing 11 female and 10 male elementary school teachers Stake \& Katz (1982) concluded that female teachers were more positive than male teachers in their attitudes and behaviour towards their students - providing a more positive classroom atmosphere overall. Responses from teachers who took part in the Hong Kong study suggest that male teachers are more authoritarian, prefer to control pupils' learning, engage pupils in whole-class reading and like to read passages aloud while pupils follow the text (Lam et al, 2010). This gives strong support to the argument that differences in student achievement is more due to differences in teacher abilities rather than the gender of the teacher as such.

However, "academic motivation and engagement does not significantly vary as a function of their teacher's gender, and boys do not fare any better with male teachers than female teachers" (Martin \& Marsh, 2005).

\subsection{Hypotheses}

1. Ho : There is no significant difference between male and female teachers based on students' results.

Ha : There is a significant difference between male and female teachers based on students' results.

2. Ho: There is no significant difference between male and female teachers based on students' results, with regard to students' gender.

$\mathrm{Ha}$ : There is a significant difference between male and female teachers based on students' results, with regard to students' gender. 


\subsection{METHODOLOGY}

\subsection{Research Design}

The quantitative method of research was used for this study. According to Creswell (2009) the quantitative methods determine whether the predictive generalization of a theory or hypothesis is accurate. With this regard, quantitative approach is any kind of research that is mainly used to test or verify theories or explanations. Thus, it identifies variables to study and relate those variables in questions or hypotheses by using statistical standards of validity and reliability, and employ statistical procedures for analysis (Creswell, 2009). A researcher who uses quantitative approach generally has a very clear idea about what is being measured before they start measuring it, and their study is set up with controls and a very clear outline (Keith, 1998). Since the aim of this research is to find out whether man or women are more suitable for teaching in primary schools, which is a gender comparison, T test was believed to be the most appropriate.

T test is used when you have one "nominal variable" and one "measurement variable", and you want to compare the mean values of the measurement variable. The nominal variable must have only two values, such as "male" and "female"..." (McDonald, 2009)

\subsection{Population and Sampling}

This research uses secondary data (test scores) of primary grades for five consecutive years which is obtained from a school in Malaysia. Two classes from grade four and two classes from grade five for a period of five years were then selected by considering the gender of teachers who taught those classes. Thus, this study engages a total of 1 school, 20 classes, 30 teachers and 604 students. Several criteria were considered in selecting the sample. The very initial idea is to obtain data for minimum of five years to make the findings accurate. Then the gender was considered in a way that tests the hypothesis as accurately as possible where both male and female teachers contributed teaching in these 20 (Twenty) classes during the sampled period. Grades 4 and 5 were chosen particularly due to this reason as there were all female or male teachers for some of the grades during the sampled period. Out of the seven subjects taught in the primary, only mathematics marks is used in the research. This is so because on one hand teacher gender has to be made as proportional as possible and on the other hand because of the nature of this study.

\subsection{Data Collection}

The research is primarily based on quantitative method where secondary data or otherwise documented data is used to test the hypothesis. Merriam (1988) defines documents as any form of data not gathered through interviews or observations. As proposed by Neuman (2006) availability of document based data or the existing statistics are first analysed to creatively fit into the research context and is collected by considering the research questions 
and variables (set out for this particular research) in mind. Documented data inform research by enhancing the credibility of the research findings and interpretations. Such data can be used to describe, understand and explain how things function at the sample sites (Merriam, 1998). The quantitative data collected for this research was obtained from city school located in the centre of Kuala Lumpur of Malaysia. The school principal was first approached through mobile phone to see the possibilities of obtaining the final mark sheets of their primary grades (levels $1-5$ ) for five years period along with the gender of the teachers who taught the specific subjects. Then, a phone call requesting for the data from the specified grades were made to make the inquiry more formal. The data was first provided for 2008, 2009 and 2010 due to unavailability of data in spread sheet format. However, upon a further request for the scanned copies of the data for 2006 and 2007, was later forwarded through email after compiling them in the spread sheet format. A further request was sent to one of the leading teacher through another phone call and a reminder was sent through a mobile text message as the data lacks the gender of the teachers who taught the various subjects for the primary grades classes during the sampled time period, i.e. from 2006 to 2010. There are many advantages and disadvantages in using secondary data. The obvious advantages in this case were the cost and time. This study used the final mark sheets of the above school for a period of five years. Although the initial design was to include all primary scores, due to limitations in obtaining data the study was narrowed down to grades 4 and 5 and also to one subject, that is Mathematics. The school mark sheets were the 5 years records of their students' marks obtained in all the subjects - of which Mathematics marks were chosen - and there is no manipulation of the research setting necessary with this.

\subsection{Data Analysis}

Since the objective of the study is to see if there is any difference between male and female teachers in the mean scores of their respective classes, the statistical analysis employed in this study is the $\mathrm{T}$ test. $\mathrm{T}$ test is calculated using a formula that has the difference between the means (of the males and females) in the numerator denoted by $X$ means. This makes the value of $t$ get larger as the means get further apart. The denominator is the standard error of the difference in the means, denoted by $\mathrm{S}^{2}$, which gets smaller as the sample variances decrease or the sample sizes increase (McDonald, 2009). Thus, the $t$ value gets larger as the means get farther apart, the variances get smaller, or the sample sizes increase. Consequently, a small $t$ value indicates the difference is statistically not significant. In order to reject the null hypothesis the probability of significance is set to 5 percent $(p=.05)$ which is the standard used in most of the researches in social science.

\subsection{Validity and Reliability}

Validity and reliability are two main characteristics of any set of data a researcher has to consider (Keith, 1998). The concept of validity is used to judge whether the research accurately describes the phenomenon that it is intended to describe. Since the primary aim of this research is to find out whether man or women are more suitable for teaching in primary 
schools, by considering the academic achievement of the students and the gender of the teachers, the validity of the data is pursued as the data is documented for their own purpose.

As suggested by Cohen, Manion, \& Morrison (2007), the standards and criteria of validity and reliability is considered as authenticity and credibility of the data. The data (students test mark) obtained was produced from the students' test scores of various years which was printed in the students' progress report. In Malaysia, most primary schools provide students' marked answer scripts back to the students which they can take home where parents can go through and reflect and compare with the students' progress report. This pursues the issue of authenticity and credibility. In this context the data is very dependable as there is no manipulation and control of any variable as the data were produced and obtained for internal and official purpose of the school.

\subsection{Limitations}

As the research is basically conducted by analysing students, academic achievement and gender of the teachers who taught them, a very fore fronted limitation is that the research does not address the other factors that might influence students, academic achievement. This includes the ability levels of the selected students' sample, socio economic background of the students, competency level and pedagogical knowledge of the teachers, and instructional support by the grade supervisors. Another limitation of the research is that it does not consider the lower grades (grades 1 to 3 ). Moreover, there is no attempt made to relate it to the other subjects since it is only the marks of Mathematics which is taken into account. As such, the researchers do not claim to generalize the findings to other subjects and even to the primary schools.

\subsection{FINDINGS}

\subsection{Impact of gender on students' test results}

In order to find the impact on students' test result, data were analyzed at two levels - first a grade wise comparison (grades 4 and 5 separately) and then comparing the aggregate results of the two grades.

\subsubsection{Finding from grade 4 data}

Table 4.1 shows the mean performance of those pupils taught by male teachers and female and also the mean for the whole group of students.

Table 4.1 Group Statistics (Grade 4) AVGMARKS 


\begin{tabular}{|l|l|l|l|}
\hline Female & 58.0000 & 12 & 7.64870 \\
\hline male & 49.2500 & 8 & 1.75379 \\
\hline Total & 53.5000 & 20 & 6.49889 \\
\hline
\end{tabular}

Based on table 4.1, the performance of female teachers is found to be better as compared to male teachers in which the mean for students taught by female teachers is 57.00 whereas for the male teachers it is 50.25 . Moreover, the performance of male teachers is also found to be even less than the average for the whole sample (53.50) while on the other hand the average for the female teachers is higher.

\section{Table 4.2 Independent Sample T Test (Grade 4)}

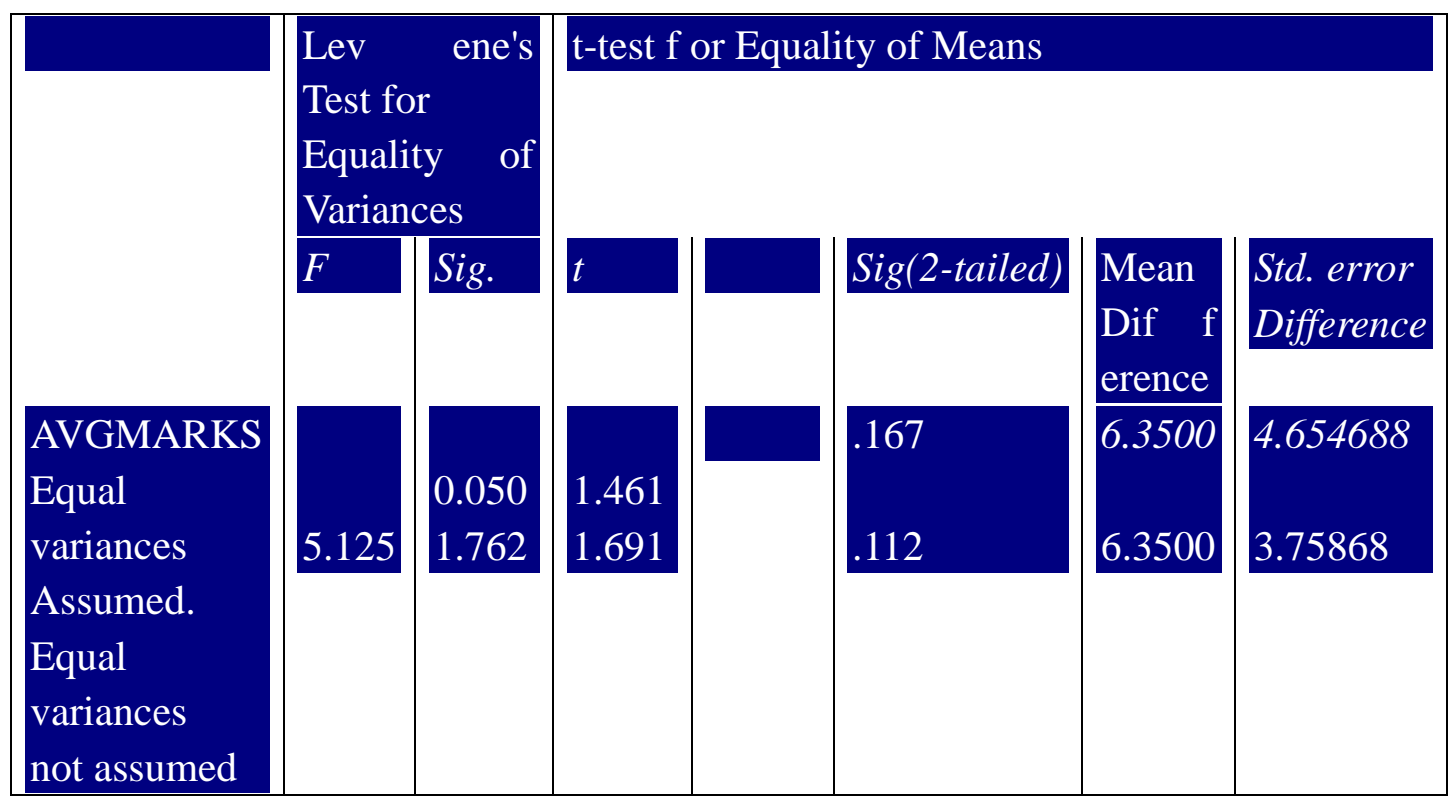

Even though women are known to perform better when referring to the arithmetic means, it is also necessary to find that the difference is statistically significant. Independent sample t test was performed for this purpose and the result is shown in table 4.2. Since that significance value is $.167(\mathrm{p}>.05)$ the null hypothesis has to be accepted. Therefore, there is no significant difference between female and male teachers based on the average of the class.

\section{b) Findings from Grade 5 Data}

Table 4.3 shows the mean performance of those pupils taught by male teachers and female and also the mean for the whole group of students of grade 5 .

Table 4.3 Group Statistics (Grade 5) AVGMARKS

\begin{tabular}{|l|l|l|l|}
\hline Teacher (Gender) & Mean & N & Std. deviation \\
\cline { 1 - 3 } Female & $\mathbf{5 8 . 3 3 3 3}$ & 12 & 4.54221 \\
\hline
\end{tabular}




\section{male}

24.7500

Total

41.5000

\begin{tabular}{|l|l|}
80 \\
\hline 20
\end{tabular}

$\frac{9.8733}{10.3407}$

Based on table 4.3, the performance of female teachers is found to be better as compared to male teachers in which the mean for female teachers is 58.33 whereas the mean for male teachers is 24.75 . As compared to the group average (41.50) female teachers are found to be doing better than that of male teachers.

Table 4.4 Independent Sample T Test (Grade 5)

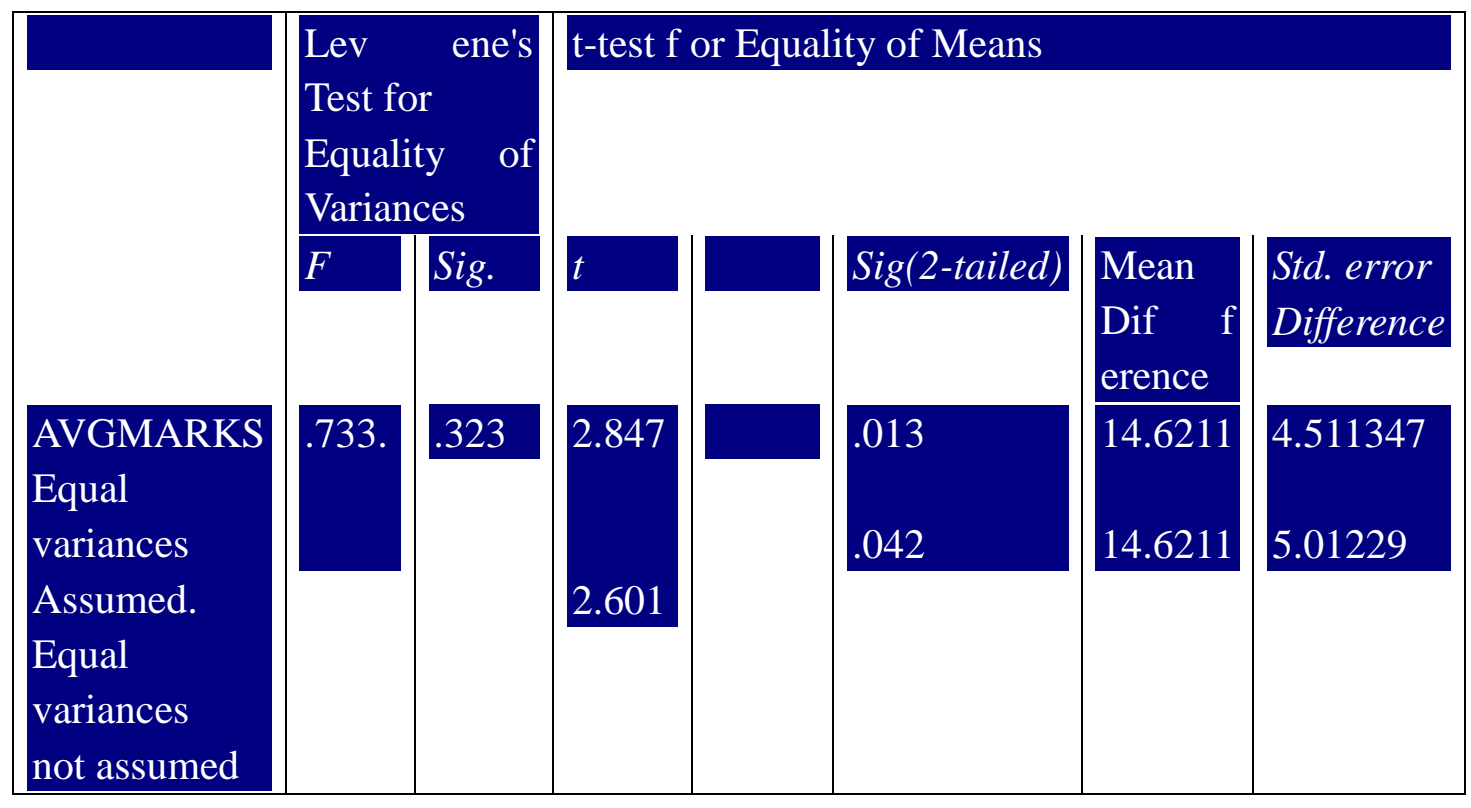

The independent sample $t$ test confirms that the observed difference in mean is statically significant as shown in table 4.4. Since the significance value is $.013(\mathrm{p}<.05)$ the null hypothesis can be rejected. Thus, in case of grade 5, there is a significant difference between female and male teachers based on the average of the class.

\section{c) Finding from Combined data}

Table 4.5 shows the mean performance of those pupils taught by male and female teachers and also the mean for the whole group of students (grades 4 and 5 combined).

Table 4.5 Group Statistics (Grade 4 and 5 combined) AVGMARKS

\begin{tabular}{|l|}
\hline Teacher (Gender) \\
\hline Female \\
\hline Male \\
\hline Total \\
\hline
\end{tabular}

\begin{tabular}{|l|}
\hline Mean \\
\hline 53.5956 \\
\hline 41.4123 \\
\hline 47.5000 \\
\hline
\end{tabular}

\begin{tabular}{|l|}
\hline N \\
\hline 20 \\
\hline 10 \\
\hline
\end{tabular}

\begin{tabular}{|l|}
\hline Std. deviation \\
\hline 7.27343 \\
\hline 11.41132 \\
\hline 11.11342 \\
\hline
\end{tabular}




\section{Macrothink}

According to table 4.5 the performance of female teachers is found to be better as compared to male teachers in which the mean for female teachers is 53.56 whereas for the male teachers the mean is 41.41 . The mean for males is also found to be lower than the mean for the whole group (47.50).

Table 4.6 Independent Sample T Test (Grade 4 and 5 combined)

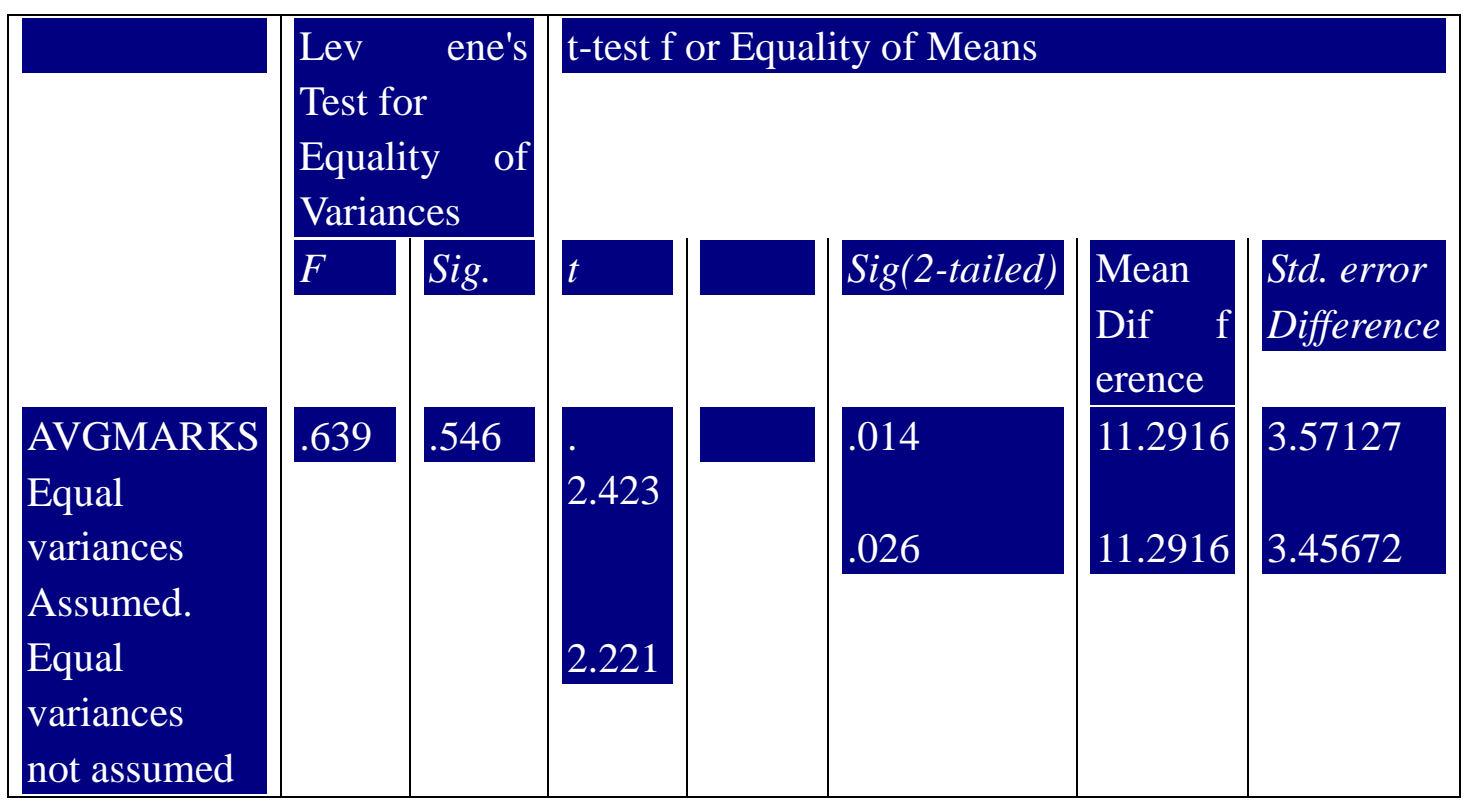

When independent sample $\mathrm{T}$ test was performed, as shown in table 4.6, it is understood that the reported difference in mean is also statistically significant (level of significance is $.014, p$ $<.05)$. Thus, the alternative hypothesis can be accepted meaning that there is a significant difference between male and female teachers based on the average of the whole group of sample.

\subsection{Male or female teachers' performance based on students' gender}

Results for this questions were also analyzed at two levels - a grade wise comparison (grades 4 and 5 separately) and then comparing the aggregate results of the two grades.

\section{a) Finding from Grade 4 Data}

Table 4.7 shows the mean performance of those pupils taught by male teachers and female and also the mean for the whole group of grade four students. 
Table 4.7 Group Statistics - cross gender (Grade 4) AVGMARKS

\begin{tabular}{|l|}
\hline $\begin{array}{l}\text { Teacher } \\
\text { (Gender) }\end{array}$ \\
\hline Boysavg: \\
Female \\
Male \\
\hline Girlsavg: \\
Female \\
Male \\
\hline
\end{tabular}
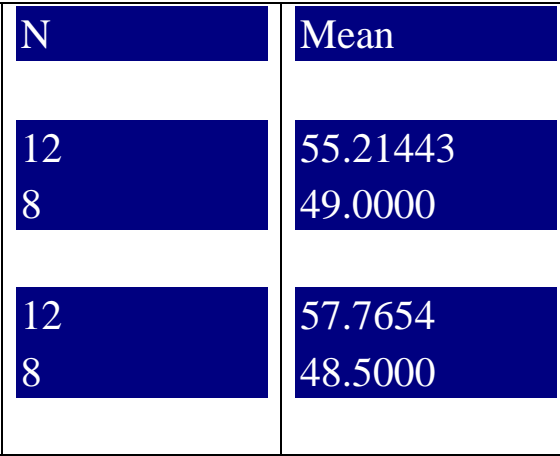

Std. deviation
10.41233
5.68134

6.32154
6.81662

\begin{tabular}{|l|}
\hline $\begin{array}{l}\text { Std error } \\
\text { mean }\end{array}$ \\
\hline 5.60034 \\
2.12345 \\
\hline \\
2.89487 \\
3.75112 \\
\hline
\end{tabular}

From the above table it shows that when compared against the average of boys, female teachers' performance was better than male teachers' where the performance of females is 55.21 and that of males is 49.00. Similarly, when the averages for girls are compared it is also found that female teachers perform better with an average of 57.76 whereas the mean for male teachers is 48.50 . Hence, when the teachers' performance is measured against the difference in achievement of boys and girls, in both the cases female teachers do better than male teachers. There is no indication that the average performances of the students when taught by teachers of alternative gender are better than the average performances of the students when taught by the teachers of corresponding gender.

Table 4.8 Independent Sample T Test - cross gender (Grade 4)

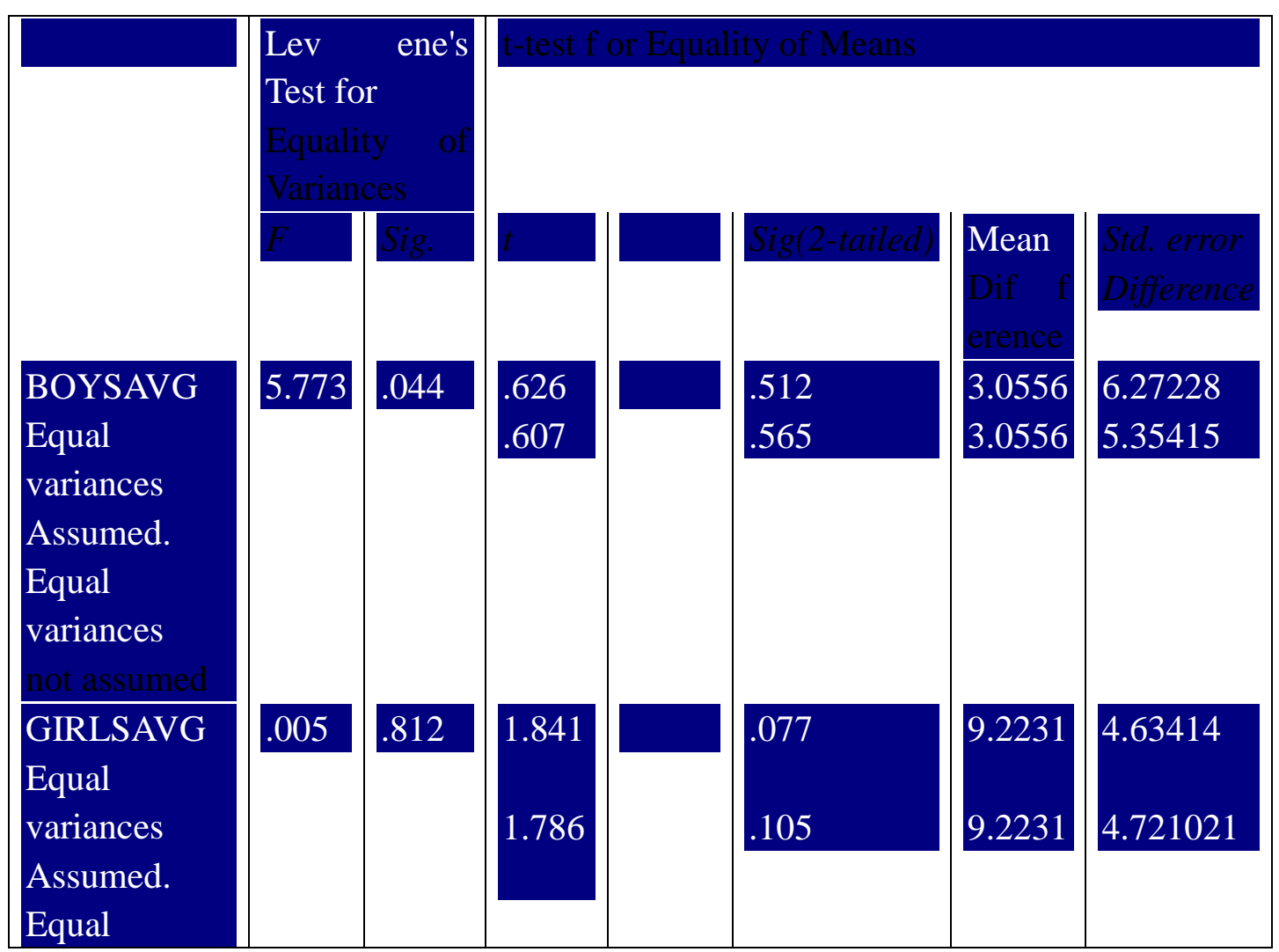




\section{variances \\ not assumed}

Although differences were observed in the arithmetic means, the test results for the data show that the existing differences are not statistically significant (Table 4.8). Since the significant value for boys is $.621(\mathrm{p}>.05)$, the null hypothesis has to be accepted. Thus, there is no significant difference between male and female teachers when the boys' performance is considered. Similarly, since the significant value for girls is $.089, p>.05$, the null hypothesis has to be accepted. Therefore, there is no significant difference between male and female teachers when the girls' performance is considered

The $t$ test was also performed to see if matching teachers' gender with students' results in any significant difference. In order to do this, the results of boys and girls are compared against the teachers' gender. Table 4.9 shows the results of this comparison.

Table 4.9 Independent Sample T Test - same gender (Grade 4)

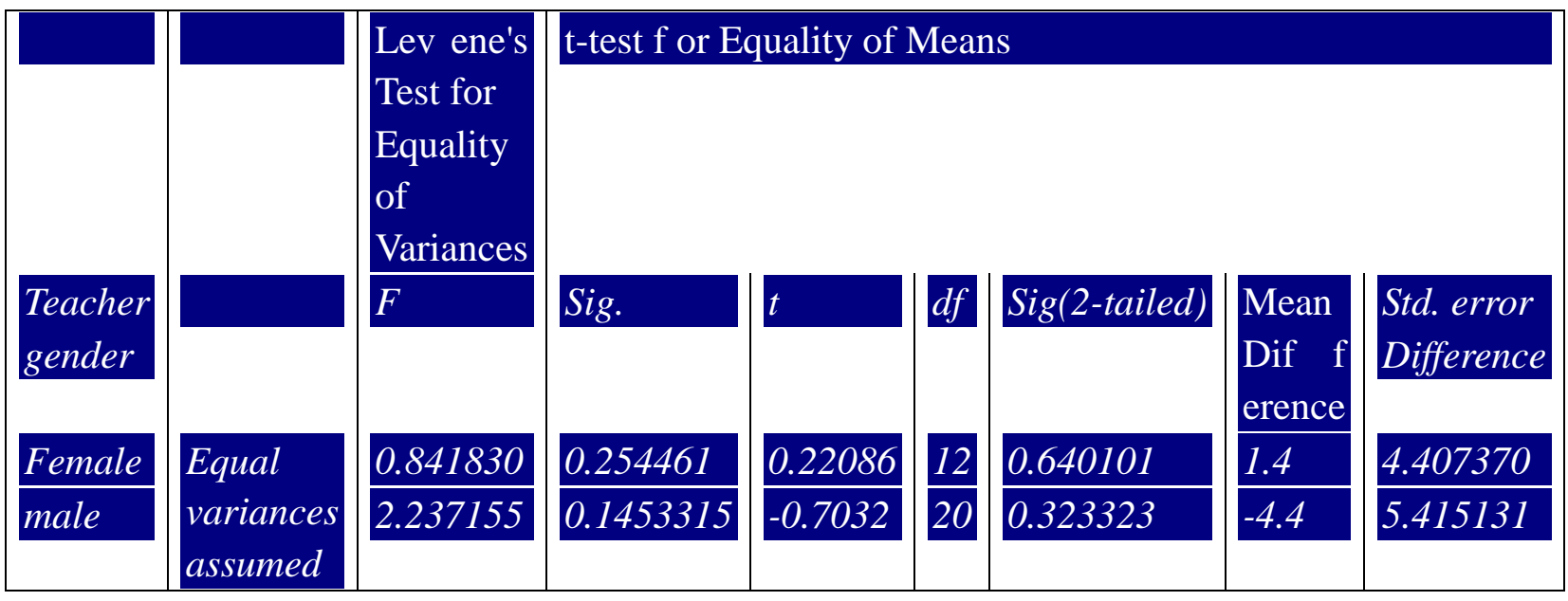

As seen from table 4.9, there is no significant difference between boys and girls irrespective of teachers' gender. When taught by female teachers the significance value is .64, p > .05 and for male teacher it is $.32, p>.05$. Hence, there is no significant difference between male and female teachers whether teach to students of same gender or otherwise.

\section{b) Findings from Grade 5 Data}

Table 4.10 shows the mean performance of those pupils taught by male and female teachers and also the mean for the whole group of students. 
Table 4.10 Group Statistics - cross gender (Grade 5)

\begin{tabular}{|l|l|l|l|l|}
\hline $\begin{array}{l}\text { Teacher } \\
\text { (Gender) }\end{array}$ & $\mathrm{N}$ & Mean & Std. deviation & $\begin{array}{l}\text { Std error } \\
\text { mean }\end{array}$ \\
\hline $\begin{array}{l}\text { Boysavg: } \\
\text { Female } \\
\text { Male }\end{array}$ & 12 & 44.0556 & 6.60461 & 2.62651 \\
& 8 & 36.4187 & 6.02611 & 3.15532 \\
\hline $\begin{array}{l}\text { Girlsavg: } \\
\text { Female Male }\end{array}$ & 12 & 8 & & \\
& & 50.7211 & 7.81880 & 3.11810 \\
& & 40.1412 & 1.14720 & \\
\hline
\end{tabular}

Table 4.10 shows that when compared against the average of boys, female teachers' performance is better with an average of 44.05 whereas male teachers produced an average of 36.42. Similarly, when the averages for girls are compared it is also found that female teachers perform better with an average of 50.72 while the mean for male teachers is 40.14 . Hence, when the teachers' performance is measured against the difference in achievement of boys and girls, in both the cases female teachers perform better than male teachers.

Table 4.11 Independent Sample T Test - cross gender (Grade 5)

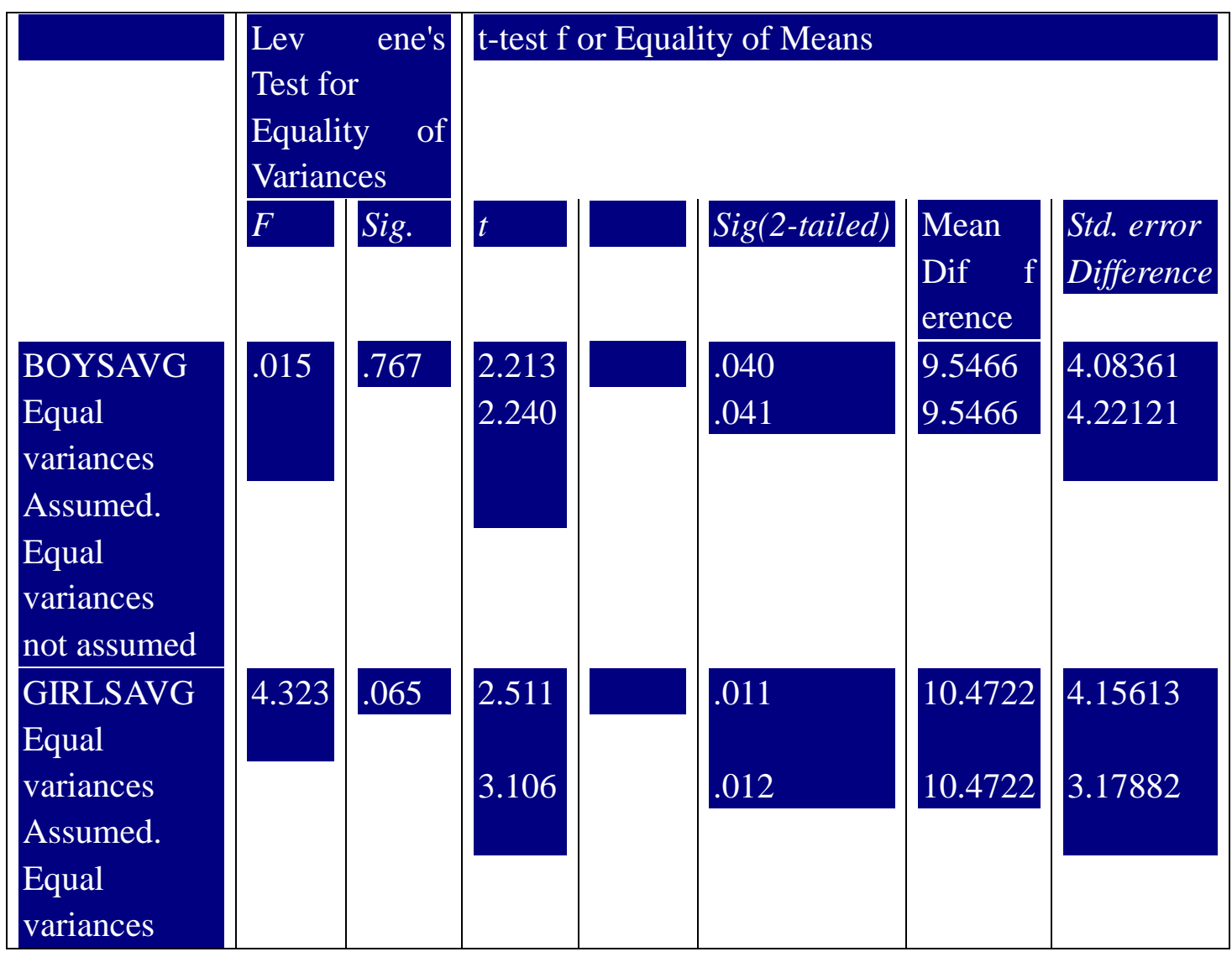


The results of $t$ test when the indicated mean differences are analysed are shown in table 4.11 which shows that the significant for boys is $.04, p=.05$ and that for girls is $.021, p<.05$. Therefore, there is a significant difference in average performance of boys and girls when taught by teachers of alternative gender.

Table 4.12 Independent Sample T Test - same gender (Grade 5)

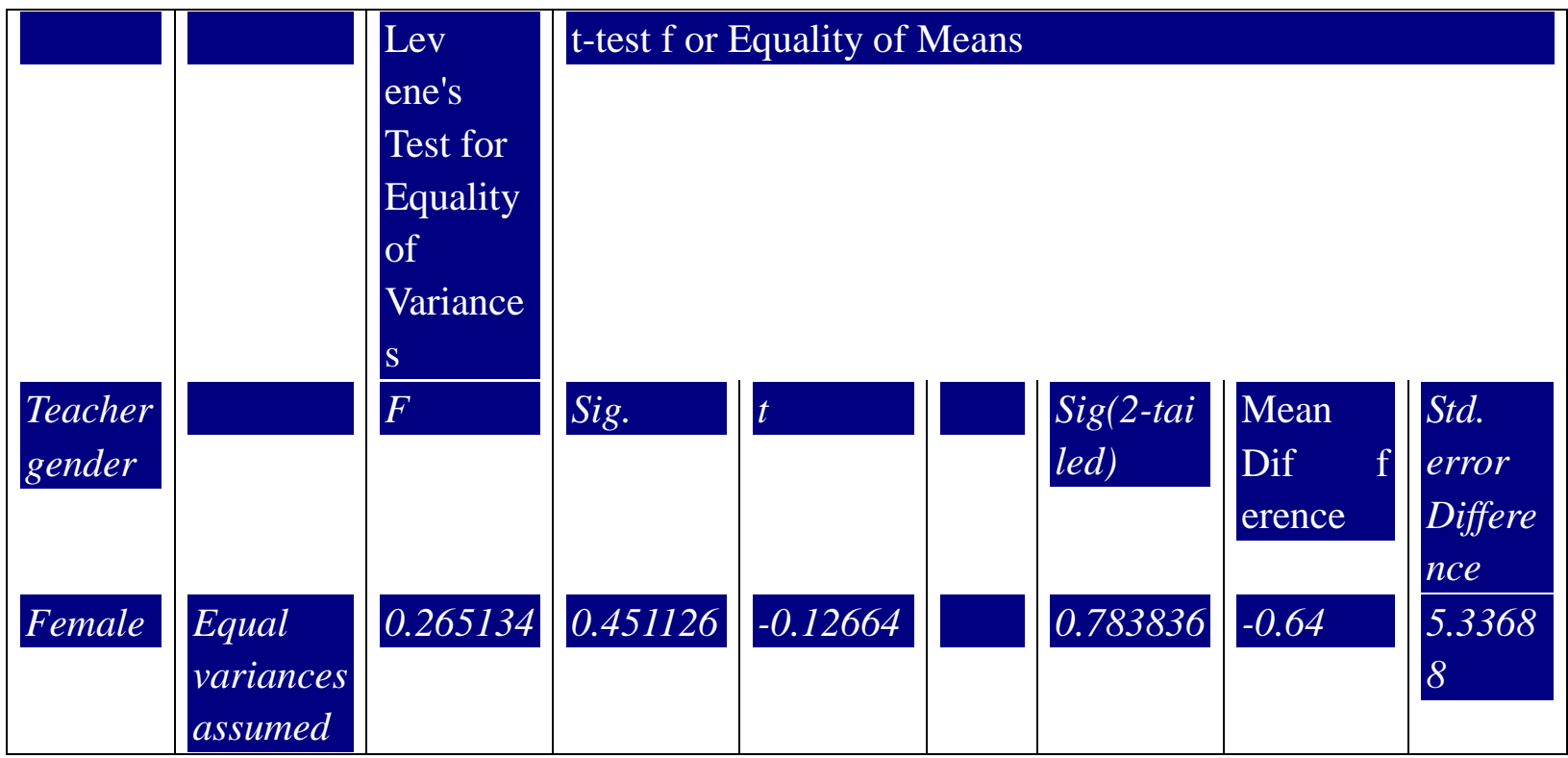

As seen from table 4.12, there is no significant difference between boys and girls irrespective of teachers' gender. When taught by female teachers the significance value is $.78, p>.05$ and for male teacher it is $.14, p>.05$. Hence, there is no significant difference between male and female teachers whether teach to students of same gender or otherwise.

\section{c) Finding from Combined data}

Table 4.13 shows the mean performance of those pupils taught by male and female teachers and also the mean for the whole group of students (grades 4 and 5 combined).

Table 4.13 Group Statistics (Grade 4 and 5 combined)

\begin{tabular}{|l|l|l|l|l|}
\hline $\begin{array}{l}\text { Teacher } \\
\text { (Gender) }\end{array}$ & $\mathrm{N}$ & Mean & Std. deviation & $\begin{array}{l}\text { Std error } \\
\text { mean }\end{array}$ \\
\hline $\begin{array}{l}\text { Boysavg: } \\
\text { Female } \\
\quad \text { Male }\end{array}$ & 20 & 48.5453 & 10.02733 & 2.81560 \\
10 & 42.1400 & 9.60531 & 3.32062 \\
\hline Girlsavg: & 20 & 56.1200 & 8.02166 & 2.21218 \\
\hline
\end{tabular}


According to the table, the average performance of boys when taught by female teachers is 48.55 and the mean is 42.14 when taught by males. This indicates that by arithmetic mean female teachers are better in teaching to boys. When comparing the averages for girls it is again found that female teachers are doing better with an average of 56.1 whereas the mean for male teachers is 44.26 . Hence, in the case of both boys and girls, female teachers perform better than male teachers. Another indication is that girls have performed better than boys when taught either by teachers of corresponding or alternate gender.

\subsection{Independent Sample T Test - cross gender (Grade 4 and 5 combined)}

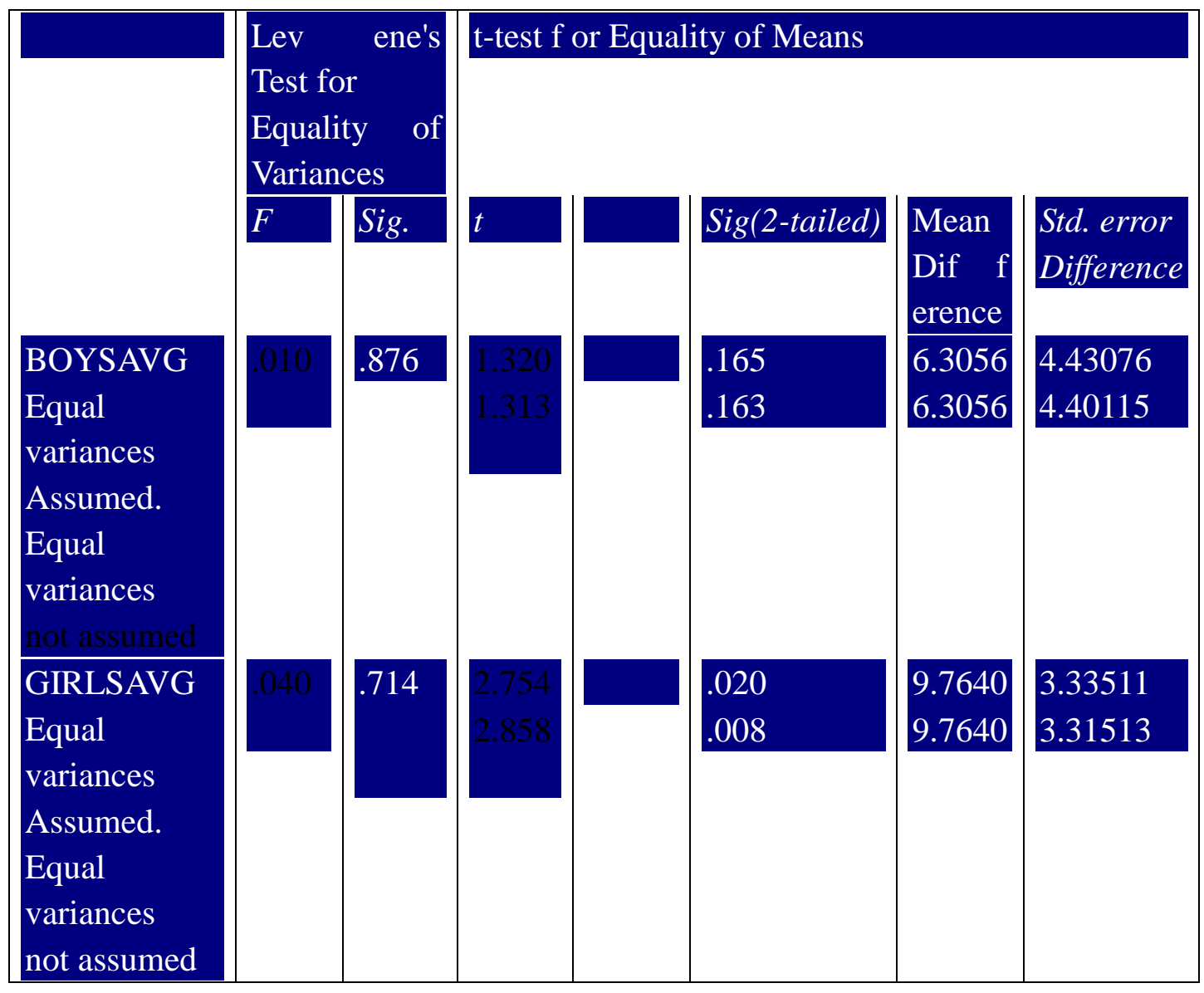

The table 4.14 shows the significant for boys is $.165, \mathrm{p}>.05$ and the significant for girls is $.020, \mathrm{P}<.05$. Therefore, there is a no significant difference between males and females when the average performance of boys is considered, but there is a significant difference between the genders when the girls' average is taken into account.

Table 4.15 Independent Sample T Test - same gender (Grade 4 and 5 combined) 


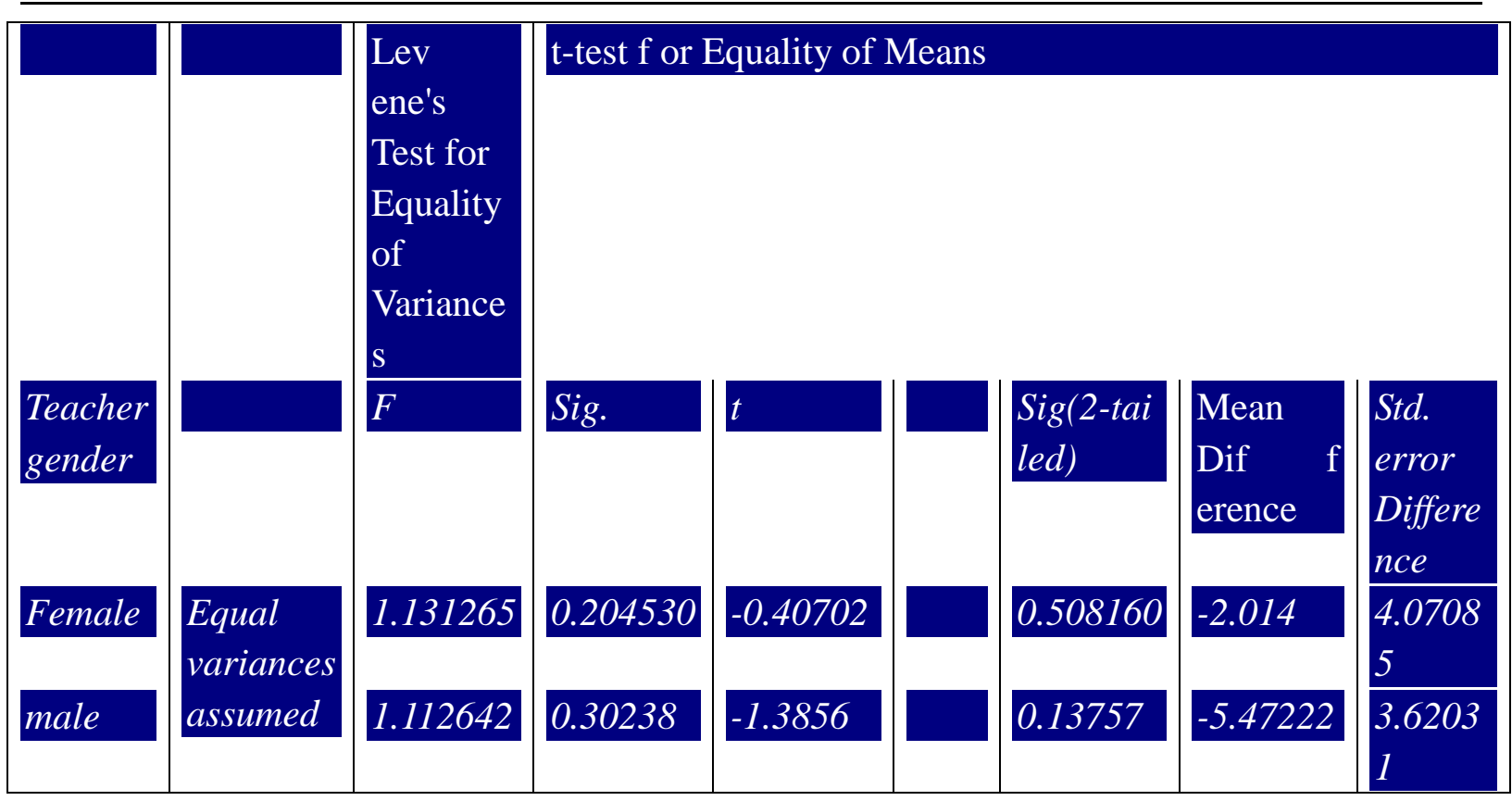

As seen from table 4.15, there is no significant difference between boys and girls irrespective of teachers' gender. When taught by female teachers the significance value is $.51, \mathrm{p}>.05$ and for male teacher it is $.14, p>.05$. Hence, there is no significant difference between male and female teachers whether teach to students of same gender or otherwise.

\subsection{CONCLUSIONS}

Since the statistics for teacher gender in Malaysia is similar to the pattern around the world it was anticipated that the findings of the study will also be similar to other findings where the majority of literature on gender differences in teaching to primary grades show that females are better as compared to males. But comparing the test scores, this study, which is unique in nature in Malaysia, found that women are better in teaching to primary. Base on the various analyses, it is concluded that teacher gender is not less important than other factors as far as student achievement in test scores are considered. In this regard, Jones (2003) concluded that instead of debating on teachers' gender as such, it is more logical to focus on choosing the "right kind of candidates". Moreover teacher' personality, natural instinct, and quality are largely considerable than gender stereo-type in the achievement of the students (Skelton et al., 2009).

\section{References}

Azza, F., \& Aishath, A. (2008): Education for all: Mid-dicade assessment - 2007. Male': Ministry of Education. Brophy,

J. E. \& Good, T.C. (1973): Feminization of American elementary schools. Phi Delta Kappan, $54,564-566$

Carrington, B., \& McPhee, A. (2008): Boys' 'underachievement' and the feminization of teaching. Journal of Education for Teaching, 34 (2), 109-120. 


\section{Macrothink}

Journal of Sociological Research

ISSN 1948-5468

2013, Vol. 4, No.1

Carrington, B., Francis, B., Hutchings, M., Skelton, C., Read, B., \& Hall, I. (2007): Does the Gender of the Teacher Really Matter? Seven- to Eight-Year-Olds' Accounts of Their Interactions with Their Teachers. Educational Studies, 33 (4), 397-413.

Carrington, B., Tymms, P., \& Merrell, C. (2008): Role Models, School Improvement and the "Gender Gap"--Do Men Bring out the Best in Boys and Women the Best in Girls? British Educational Research Journal, 34 (3), 315-327.

Creswell (2009): Research Design: Qualitative, Quantitative, and Mixed methods Approaches. New Delhi: SAGE Publications.

Connell, R.W. (1996): Teaching the boys: New research on masculinity, and gender strategies for schools. Teachers College Record, 98(2), 206-235

Cohen, L., Manion, L., \& Morrison, K. (2007) : Research Methods in Education, Sixth Edition. Routledge: Madison Avenue, New York

Dee, T. S. (2007) : Teachers and the Gender Gaps in Student Achievement. The Journal of Human Resources, 3 (XLII), 528-554.

Driessen, G. (2007) : The feminization of primary education: effects of teachers ${ }^{\text {ee }}$ sex on pupil achievement, attitudes and behaviour. Review of Education (53), 183-203.

Ehrenberg, R. G., Goldhaber, D. D., \& Brewer, D. J. (1995) : Do teachers' race, gender, and ethnicity matter? evidence from the national educational longitudinal study of 1988. Industrial and Labor Relations Review, 48 (3), 547-561.

Francis, B., Skelton, C., Carrington, B., Hutchings, M., Read, B., \& Hall, I. (2008) : A perfect match? Pupils' and teachers' views of the impact of matching educators and learners by gender. Research Papers in Education, 23 (1), 21-36.

Greenburg, M. (1977) : The male early childhood teacher: An appraisal. Young Children, 37, 34-37.

Hopf, D., \& Hatzichristou, C. (1999) : Teacher gender-related influences in Greek schools. British Journal of Educational Psychology, 68 (1), 1-18.

Hoque KE, Alam GM, \& Abdullah AGK (2010): Impact of teachers' professional development on school improvement: an analysis at Bangladesh standpoint. Asia Pacific Educ. Rev., DOI 10.1007/s12564-010-9107-z. In press.

Jones, D. (2003) : The ,righte kind of man: The ambiguities of re-gendering the early years school environment - the case of England and Wales. Early Child Development and Care, 173 (6), 565-575.

Karieg, J. M. (2005): Student Gender and Teacher Gender: What is the Impact on High Stakes Test Scores? Current Issues in Education [On-line], 8 (9).

Kaplan, L. (1947): The status and functions of men teachers in urban elementary schools.Doctoral dissertation, University of Southern California.

Keith, F. P. (1998): Introduction to social research, Quantitative and Qualitative Approaches. New Delhi: Thousand Oaks.

Lam, Y. H., Tse, S. K., Lam, J. W., \& Loh, E. K. (2010): Does the gender of the teacher matter in the teaching of reading literacy? Teacher gender and pupil attainment in reading literacy in Hong Kong. Teaching and Teacher Education (26), 754-759.

Levine, J.A. (1977): Redefining the child care problem: Men as child nurturers. Child Education, 54, 55-61. 


\section{MInstitute Macrothink $_{\text {Int }}$}

Journal of Sociological Research

ISSN 1948-5468

2013, Vol. 4, No.1

Luschei, T. F. (2011) The effectiveness and distribution of male primary teachers: Evidence from two Mexican states. International Journal of Educational Development, (In press).

Majzub, R. M. \& Rais, M. M. (2010) Boys' Underachievement: Male versus Female Teachers. Social and Behavioral Sciences, 7, 685-690.

Malaysia (2010) Statistics of teachers by gender. Kuala Lumpur, Malaysia ; Ministry of Education

Mariyam, N. (2009): Country paper from Maldives: Innovative Practices in TVET towards education for sustainable development (Conference paper). The International Experts meeting on "Reorienting TVET Policy towards Education for Sustainable Development". Berlin, Germany.

Martin, A., \& Marsh, H. (2005, November): Motivating boys and motivating girls: does teacher gender really make a difference? Retrieved April 04, 2011, from Australian Journal of Education (online version): http://goliath.ecnext.com/coms2/gi_0199-5013070/Motivating-boys-and-motivating-girls.htm $\underline{1}$

McCandless, B. R., Bush, C., \& Carden, A. I. (1976): Reinforcing contingencies for sex-role behaviors in preschool children. Contemporary Educational Psychology, 1 (3), 241-246.

McDonald, J. H. (2009): Handbook of Biological Statistics (2nd ed). Maryland, USA: Sparky House Publishing.

MDP Alliance. (2008): Aneh Dhivehiraajje: Polcies of the MDP alliance. Retrieved February 23, 2011, from http://voteanni.com/aneh_dhivehi_raajje_manifesto.pdf

Meece, J. L. (1987): The influence of school experiences on the development of gender schemata. New Directions for Child and Adolescent Development (38), 57-73.

Merriam, S. (1998): Case study research in education: A qualitative approach. London: Jossey-Bass.

Ministry of Planning and National Development. (2005). Millenium Development Goals: Maldives Country Report. Male': Ministry of Planning and National Development.

MOE. (2011): Education Statistics, Dhaka: Ministry of education, People Republic of Bangladesh

Myhill, D., \& Jones, S. (2006): 'She doesn't shout at no girls': pupils' perceptions of gender equity in the classroom. Cambridge Journal of Education, 36 (1), 99-113.

ORegan, B. (2007, August 27): Females better at teaching reading to boys: Study. Retrieved February 10, 2011, from http://www.nowpublic.com/females-better-teaching-reading-boys-study

General Economics Division (2009): The Millennium Development Goals, Dhaka: Planning Commission, People Republic of Bangladesh

Rodriguez, N. (2002): Gender Differences in Disciplinary Approaches. ERIC Document SP041019.

Seifert, K. (1985). Career experiences of men who teach young children. Canadian Journal of Early Childhood Education, 1, 65-74.

Skelton, C. (2002): The „feminisation of schoolingee, or „re-masculinisingee primary education. 


\section{Macrothink}

International Studies in Sociology of Education, 12 (1), 77-96.

Skelton, C., Carrington, B., Francis, B., Hutchings, M., Read, B., \& Hall, I. (2009): Gender „matters ${ }^{\text {ee }}$ in the primary classroom: pupilse ${ }^{\text {ee }}$ and teachers ${ }^{\text {ee }}$ perspectives. British Educational Research Journal, 35 (2), 187-204.

Stake, J., \& Katz, J. (1982): Teacher-Pupil Relationships in the Elementary School Classroom: Teacher-Gender and Pupil Gender Differences. American Educational Research Journal (19), 465-471.

Tubbs, E.V. (1946): More men teachers in our schools. Schools and Society, 63, 394.

World Bank (2010): Bangladesh - Primary Education Development Support Project (Washington, DC, USA: World Bank, Integrated Safeguards Data Sheet, No. AC5354; August). 